\title{
THE DILEMMA OF DIRECT SELLING IN CHINA
}

\author{
Yuexin Miao \\ Central University of Finance and Economics, P.R.China
}

\begin{abstract}
Direct selling has a history nearly 100 years, many scholars have given out their opinions about what is direct selling, but in fact the concept of direct selling is not clear. However, what is direct selling is not the question puzzled the people in China. In practical, the key issue is the ethical problems aroused by multilevel direct selling that give a bad name to the direct selling as a whole in its market. Keeping the main characteristics of this business model and blending with the Chinese social and economic needs, it is the most practical way of developing this industry.
\end{abstract}

Key words: Direct selling, Chinese market, Multilevel direct selling

\section{JEL code: M31}

In recent years, direct selling is one of the focuses of debate in Chinese market. Because the problem of single-level marketing is legal and multilevel marketing is illegal, this leads to not being aligned direct selling concept and the direct selling practice.

\section{The Concept of Direct Selling}

As Merrilees and Miller (1999) pointed out, actually, not a lot is known about direct selling and especially the new forms of direct selling, such as multi-level selling and Internet commerce in China. As an industry, globally, direct selling has a history nearly 100 years, but in fact the concept of direct selling is not clear. According to World Federation of Direct Selling Association (WFDSA), it involves the marketing of products and services directly to consumers in a face-to-face manner, away from permanent locations, its definitions may vary from jurisdiction to jurisdiction, it might be helpful to present a generic definition widely understood and accepted. In Stanworth's and other similar's research in 2004, and also by the Federation of European Direct Selling Associations in 2003, it has been defined as the marketing of consumer goods and services directly to consumers on a person-to-person basis, generally in their homes, or the homes of others, at their work place and other places away from a permanent retail location.

Many scholars have given out their opinions about what is direct selling. Duffy (2005) pointed out direct selling is the process of selling a consumer product or service from one person to another, in an environment that does not have a permanent retail location. Ferrell and Ferrell (2012) pointed out abstract direct selling is built on the premise of leveraging an individual's social networks. Direct selling is a method of marketing and retailing products 
and services directly to the consumer via person-to-person or party plan selling. Customers are given the opportunity to see, touch, and test a product at their own leisure, often in their own homes. A diverse set of products are sold and include such traditional fare as cosmetics and skin care, vacuum cleaners, and household cleaning goods. Crittenden and Crittenden (2004) gave out their concept of direct selling: a flexible work schedule, a chance to own their own business, and social interaction (it is a good way to increase their customer network), moreover, and perhaps most important, earnings are proportionate to performance, thus eliminating the artificial barriers often found in corporate cultures, are among the main reasons why people take part in direct selling.

However, up to now, what is direct selling is not the question puzzled the people in China, the issue is the ethical problems aroused by multilevel marketing that give a bad name to the direct selling as a whole in its market. As multilevel marketing is a subcategory or branch of direct selling, it is very popular in many places in the world, sometimes it is even recognized as modern direct selling model and has an important position in the direct selling industry, so prohibiting it puts the government in a difficult situation. Still many people view the multilevel direct selling as an unethical practice as it is often considered a pyramid scheme and it is not easy to separate the two with.

\section{The Problems Related with Multilevel Marketing}

So, the main problem for government in developing direct selling in China is setting up a system by which to identify pyramid scheme from multilevel direct selling. However, as the line between multilevel marketing and pyramid scheme is not very clear, and the methods of controlling pyramid schemes that use the shape of multilevel marketing is not easy. Note in China multilevel direct selling and pyramid schemes are illegal. Even in many other countries of the world where multilevel direct selling is legal, the attitudes of consumers to this selling model are not positive. In a research made by Kustin and Jones (1995), it is found that direct selling as a method of non-store retailing, has continued to increase in popularity in Australia, by examining consumers' perceptions, their results indicated that consumers were generally negative and suspicious towards network marketing in Australia. Here, network marketing is equal to multilevel marketing in its practice. In some developed countries, as the marketing foundations have been slowly build, consumer groups are able to identify what is a pyramid scheme to understand negative ramifications of pyramid schemes and can tell the difference between a pyramid scheme and more traditional multilevel market. So it is not easy for pyramid scheme using the form of multilevel marketing to gain traction in the market. Supporting these consumers is a set of laws regulation the business practices of direct selling marketers.

But different from developed countries, the Chinese direct selling market is a new one. Direct enterprises emerged in China during the late 1980s, Avon was the first large scale direct selling enterprise to invest in China. Later, other foreign direct selling enterprises began to invest. By 1997, China had a total of 2,300 domestic and international direct-selling firms, employing as many as 20 million people and a sales volume of $\$ 2$ billion. In the meanwhile 
many unscrupulous multilevel marketers took use of the weak regulatory environment, and were able use selling tricks to lure naive Chinese consumers into buying expensive yet inferior products. For protecting interests of consumers, market order and social stability, a blanket ban was issued by government on all forms of direct-selling activities in April of 1998 . And the industry encountered a major setback as Chan pointed out. From 1992 to 2005, the China direct selling industry was in the period of preparing for the formal opening of this industry, and as a result the laws and regulations related with direct selling changed frequently. In 2005, WTO regulations said China had to open its direct selling industry to foreign competitors.

Direct selling is different from direct marketing, such as the business modes of Dell and Alibaba, Direct selling is a small industry by its retail volume in the world, the expense per capita of the world is only 25 \$. In 2015, the total direct selling market of China was not more than 200 billion Yuan, and the total number of direct sellers in this market was 3.5 million. Currently the retail volume of this market only represents $0.3 \%$ of China's total GDP. But it is now the second largest direct selling market in the world, its global market share is 19\%, second to the U.S. which has market share of $20 \%$. In Chinese regulations related with direct selling industry, especially in Administration of Direct Selling Regulations and in Prohibition of Pyramid Selling Regulations, direct selling has its unique meaning, it only includes single level direct selling. Multilevel direct selling was not included. In the Prohibition of Pyramid Selling Regulations, multilevel direct selling and pyramid scheme actually are called pyramid selling and are illegal, although no any clause in these regulations mentions multilevel direct selling or pyramid schemes. In Administration of Direct Selling Regulations which governs the direct selling market of China, and direct selling as a means of distribution by which a direct selling enterprise can recruit direct sellers to directly market its products to the end consumers outside a fixed business premises. In Prohibition of Pyramid Selling Regulations, pyramid selling means acts that interfere with economic order and affect social stability by which an organizer or operator recruits personnel and seeks to gain illegal benefits by means of calculating and paying remuneration to the recruited personnel on the basis of the number of personnel directly or indirectly recruited by them or their sales performance, or recruiting the recruited personnel to pay certain fees as a condition of being qualified for participation. By these regulations, the up line and down line multilevel direct selling model is considered a pyramid and as a result is regarded as illegal behavior.

According to the written character, "direct selling" means directly, not through other level, or by another person's help, so the single level direct selling can be accepted without doubt. But as to multilevel direct selling, it means through other people and need another person's help, so it isn't really direct. It may mean a product transferring through many hands before it reaches the final user. Therefore, when the international direct selling industry first entered in the Chinese market, the Chinese translation of "direct selling" was not accurate, was first translated as goods that require many people to handle it. Up until in 2005, "direct selling" was formally used in the article of the government regulations. This is the main reason why a lot of people in China are confused to what direct selling actually means. 
In my opinion, it is an important objective direct selling model is to promote the development of the country. With respect to the choice of direct selling model, it should not be constrained by the concrete questions such as "what is direct selling", "what kind of direct selling must we have" or other academic definition strictly. So, keeping the main characteristics of this business model and blending with the social and economic needs, it is the most practical way of developing this industry.

Enterprises, consumers and regulators are all stakeholders of the direct selling market. The choice of direct selling model depends on the compare of interests and strengths these partners. On behalf of the public, I believe regulators need to supervise direct selling industry and come up with concrete solutions. From the products and services provided by enterprises, the consumers get many benefits. The direct selling enterprises can profit by providing products and services to the market.

\section{The Future of Chinese Direct Selling Industry}

I believe the Chinese current direct selling law is a kind of system which reflects core concept of direct selling, and be suitable for the situation of China direct selling market and has its own characteristics. The role of this law has been proved effective in helping the practice develop the direct selling industry. In recent years, China's direct selling industry developed quickly and has made a big jump in the total sale volume compared with other countries. This trend confirms the view point of Duffy in 2005 that direct selling is vibrant and successful and it represents a potential new channel for many traditional companies. As the market place more and more cluttered with competition and as consumers become more well informed, the direct selling industry will represent the next frontier. Duffy sees China's direct selling industry entering a large expansion period. According to the development report of direct selling industry, which is released by the China Commerce Department, in Chinese direct selling market, more than half are foreign enterprises, including Amway, Avon, Marry Kay and $\mathrm{Nu}$ Skin. By the end of 2016, there are 82 enterprises in China, and foreign enterprises 27.

However, the history of China's direct selling industry is shorter than many other countries. Now, in my opinion, the market-oriented reform in China is at a critical period. So, if China wants to the direct selling industry to continue to develop, the actual situation of the Chinese market must be considered, and the actual capacity of Chinese society should be considered. As the direct selling is a kind of selling mode which mainly relies on the particular social networks and expanding sales channels, the process of the setting up of legal system is important. In order to do this, first economic development need and the stability of the society should be considered. In 1999 Merrilees and Miller's study by comparing the effectiveness drivers from an Asian country (China) and a Western country (Australia), found that relationship elements are more important in China, which is consistent with other studies comparing Western and Asian cultures.

The complexity of direct selling, especially multilevel direct selling, has been noticed by many researchers from different angles, such as trust, relationship, loyalty, tolerance of defect, 
and even emotional contagion. Poon, et al. (2012) argued when direct selling is considered in a global context, a salesperson has to develop trust with consumers during their interpersonal interaction in order to have better sales and develop long-term relationships. Loyalty means that the customer will be loyal to the company they identify with and try to persuade others to use this company. Wu and Tsai (2008) gave view that a tolerance of defect indicates the consumer will forgive mistakes from or negative information about the company. However, Wei, et al. (2010), pointed out, a direct selling company does not only sell products, but also sells interpersonal relationships. In direct selling industry, emotional contagion is a common phenomenon, also it is a tool used by the enterprises in recruiting processes. So, according to the view of Hashim, et al., the regulating of direct selling behavior should be treated seriously by local governments. Same as any other country in the world, China's economic development has a high degree of dependence on social stability. As Johnson-George and Swap pointed out that trust is a basic feature of all social situations, the development of any industry must not set up on the basis of the destruction of the whole social stability.

Because much of relationship marketing practiced in the western world would not apply in China. In my opinion, foreign direct selling companies additionally need to learn product knowledge, selling skills, learn the knowledge about Chinese culture, in particular relationship development, and incorporate this into the firm's sales training program. As Luk, et al. argued that the selling techniques should be modified in tune with the cultural requirements to facilitate selling and to elicit favorable responses from relatives or close friends. But, relationship management is a product of social culture, and if overuse it for the purpose of making profit, it will damage the foundation of Chinese society. Therefore, considering China's current economic development level, legal system construction and the maturity of consumers, I believe China should limit the direct selling enterprises paid model to a single level, this is the choice of a more accord with national conditions.

Nevertheless, from the perspective of direct selling enterprises, they always want to be able to adopt multilevel direct selling, because this method will bring more benefits, also facilitate enterprises to operate according to international popular way, and reduce the management and operation cost. However, considering the China's market economy now is in the transition period, a lot of unpredictable contradictions may be released, so from this angle to protect consumer interests and facilitate law enforcement, the direct selling industry positioning in a "standard development" stage is more appropriate, and that multilevel direct selling become a legal behavior has still a long way to go, in my opinion.

At present in China, there is no specifically organization such as the direct selling association to contact with and under work in the direct of the WFDSA, thus for the moral evaluation of conformance of direct selling enterprises operation and management is usually made by the associated supervise departments. Therefore, for the enterprises in the Chinese direct selling market, WFDSA's Code of Ethics itself is only a reference and has not binding effect. Starting from the actual situation of the direct selling industry development of China, the most important task facing the Chinese direct selling enterprises is to operate under the current laws, which related with the direct selling and the fight against pyramid selling. 


\section{Conclusion}

Over the past few years China's direct selling market has grown rapidly. However, to reach its future growth potential, companies in this space, in our opinion, need to find ways to incorporate more traditional Chinese societal characteristics into their current business model. Because of multilevel direct selling is similar in its form to that of a pyramid, consumers usually have a negative attitude towards the industry and pullback when they confront. This sentiment has persisted ever since the business model arrived in China. At present the laws governing the Chinese direct selling market are still being developed. Consumer behavior toward multi-level marketing products and services to some extent is not rational. The Chinese government has established some laws to regulate the current business activities of direct selling firms. Therefore, in my opinion, it is necessary for these direct selling enterprises to explore new types of direct sales models, specifically ones that are both in line with the basic direct selling operational principles and that integrate the important elements of the China's traditional culture while at the same time do not harm the existing social structure and economic order. The innovation and promotion of a new direct-sales model may face a certain amount of market risk. Going forward, should direct selling be successful in activating untapped potential market, increasing employment numbers and improving the overall competitiveness within the industry, future government regulation may not be constraining. On the other hand, if the business model expands so to the extent that the social structure and the market order are negatively impacted, government lawmakers may go in a different direction. In order to solve these dilemmas and create a new direct sales model offshoot, the industry needs to balance the relationship of the three main market players: the direct selling enterprises, the consumers and the regulators, and needs to keep balance in the process of pursuit profit maximization, rational consumption, and maintaining legal environment and social stability.

\section{References}

Chan Ricky Y. K.(1999) "At the Crossroads of Distribution Reform: China's Recent Ban on Direct Selling", Business Horizons, September-October 1999, 41-46.

Crittenden V. L. \& Crittenden W. F. (2004) "Developing the sales force, growing the business: The direct selling experience", Business Horizons 47/5 September-October 2004 (39-44).

Duffy D. L., (2005) "Direct selling as the next channel", Journal of Consumer Marketing, Vol. 22 Iss 1 pp. $43-45$.

Ferrell L. \& Ferrell O. C. (2012) "Redirecting direct selling: High-touch embraces high-tech", Business Horizons 55, pp. 273-281.

Hashim J., Wok S. \& Ghazali R. (2008) "Organisational behaviour associated with emotional contagion among direct selling members", Direct Marketing: An International Journal, Vol. 2 
Iss 3 pp. $144-158$.

Johnson-George \& Swap (1982) "Measurement of specific interpersonal trust: construction and validation of a scale to assess trust in a specific other", Journal of Personality and Social Psychology, Vol. 43 No. 6, pp. 1306-17.

Kustin, R. A. \& Jones, R. A. (1995) "Research note: a study of direct selling perceptions in Australia", International Marketing Review, Vol. 12 Iss 6 pp. 60 - 67.

Liao Shu-hsien, Chen Y. J. \& Hsieh Hsin-hua (2011) "Mining customer knowledge for direct selling and marketing”, Expert Systems with Applications, 38, 6059-6069.

Luk Sherriff T. K., Fullgrabe L. \& Li Stephen C. Y. (1999) "Managing Direct Selling Activities in China: A Cultural Explanation", Journal of Business Research 45, 257-266 .

Merrilees, B. \& Miller D., "Direct Selling in the West and East: The Relative Roles of Product and Relationship (Guanxi) Drivers", Journal of Business Research, 45, 267-273 (1999).

Poon P., Albaum G. \& Chan Peter Shiu-Fai (2012) "Managing trust in direct selling relationships", Marketing Intelligence \& Planning, Vol. 30 Iss 5 pp. 588 - 603.

Stanworth J., Brodie S., Wotruba T. \& Purdy D. (2004) "Outsourcing salesforces via self-employment: the case of direct selling in the UK", Journal of Small Business and Enterprise Development, Vol. 11 Iss 1 pp. $50-59$.

Wei Chun-Chin, Sheen Gwo-Ji, Tai Cheng-Ting \& Lee Kuo-Liang (2010) "Using Six Sigma to improve replenishment process in a direct selling company", Supply Chain Management: An International Journal, Vol. 15 Iss 1 pp. $3-9$.

Wu Wann-Yih \& Tsai Cheng-Hung (2008) "The empirical study of CRM", International Journal of Commerce and Management, Vol. 17 Iss 3 pp. $194-210$. 